\title{
MASYARAKAT UTILITARIAN, AGAMA, DAN KEHIDUPAN EKONOMI
}

\author{
Agung Riyardi \\ Fakultas Ekonomi Universitas Muhammadiyah Surakarta
}

\begin{abstract}
Utilitarianism community utilizes individual sovereignty as the most preferable factor to promote economic. Religion(s) is one of others, when individual sovereignty can not promote economic. But to promote economic, religion(s) has to appropriate with individual sovereignty. From this view, Adam Smith argues religions and not one religion in the community to promote economic. Unfortunately it can come to conclude that religion(s) does not exist in the utilitarianism community.
\end{abstract}

Keywords: utilitarianism, individual sovereignty, to promote economic, religion

\section{PENDAHULUAN}

Apakah agama memiliki peranan dalam kehidupan ekonomi di tengah masyarakat? Jika ada, bagaimanakah bentuk agama yang memiliki peranan dalam kehidupan ekonomi? Pertanyaan ini banyak diajukan, dan berusaha diuji dan dibuktikan kebenaran jawabannya setelah terjadi shift parudigm dari masyarakat dengan inner drive agama menjadi masyarakat dengan inner drive utilitarian.

Memang terdapat perbedaan signifikan di antara kedua jenis masyarakat baik dilihat dari sisi sejarah kemunculan masyarakat utilitarian yang memarginalkan agama, maupun dilihat dari orientasi masyarakat utilitarian yang lebih menitikberatkan pada orientasi materialistik. Permasalahannya, masyarakat utilitarian tetap mengakomodasikan agama dan meletakkannya dalam suatu posisi substruktur utilitarian. Dengan mengibaratkan pada dua warna yang berbeda, dimana agama adalah warna hitam dan utilitarianisme warna putih, masyarakat ulititarian memimpikan dapat meletakkan warna hitam, yaitu agama, secara serasi dalam warna putih, bahkan masyarakat utilitarian memimpikan kombinasi hitam-putih tersebut mampu memunculkan warna baru yang lebih indah, seperti pelangi.
Kenyataannya, individu dan masyarakat penganut agama pada masyarakat utilitarian berusaha melakukan berbagai penyesuaian (adjusment), supaya terjadi kesesuaian antara agama--yang dianutnya, dengan utilitarian-yang melingkupinya. Berbagai usaha adjustment tersebut yang telah dilakukan oleh individu dan masyarakat, dicatat dan dicermati oleh para pengamat, di antaranya yang dikemukakan di sini adalah pencermatan Max Weber, M. Sobari, Radjasa Mu'thasim dan Abdul Munir Mulkhan.

Max Weber, sebagai perintis dalam mengamati hubungan antara agama dengan kehidupan ekonomi telah menjawab dengan jawaban bahwa (pembaharuan) agama mempengaruhi etos kerja. Linier dengan hasil pengamatan Max Weber, M. Sobary, dan Radjasa Mu'thasim dan Abdul Munir Mulkhan mencermati kasus per kasus di beberapa daerah di Indonesia.

Namun demikian, Brue (2000) meragukan kesimpulan Max Weber. Berdasarkan pendapat para pengkritik Max Weber, dikemukakannya bahwa agama dimanfaatkan untuk kepentingan tertentu atau agama disalahgunakan. Faktafakta dalam masyarakat utilitarian mengenai 'penyalahgunaan' agama relatif luas. Agama 
dapat digunakan untuk meraih uang, agama dapat digunakan untuk meraih kekuasaan, bahkan agama dapat digunakan untuk menghancurkan. Sebagian (besar) masyarakat memang menggunakan tameng agama untuk tujuan-tujuan konstruktif utilitarianis, namun sebagian (kecil) yang lain, menggunakan tameng agama untuk tujuan-tujuan destruktif utilitarianis. Oleh karena itu, di samping kesimpulan sementara (yang kuat) agama berpengaruh dalam kehidupan ekonomi, dapat pula diambil kesimpulan bahwa agamapun juga bisa tidak berpengaruh dalam kehidupan ekonomi. Kehidupan ekonomipun bisa berpengaruh terhadap agama.

\section{HIPOTESIS AGAMA MEMPENGARUHI KEHIDUPAN EKONOMI}

Max Weber (1920) [2000], dalam karyanya The Protestant Ethict and The Spirit of Capitalism, yang terbit pada tahun 1920, kemudian diterbitkan ulang pada tahun 1958, serta dialihbahasakan dalam bahasa Indonesia pada tahun 2000, mengemukakan kesimpulan bahwa sekte agama Protestant, Calvinisme, telah berhasil mentransformasikan makna Call (seruan/ panggilan tuhan) di kalangan penganutnya, sedemikian rupa sehingga para penganut Calvinisme terdorong untuk bekerja keras untuk mendapatkan uang dan berbagai kepuasan hidup.

Transformasi makna seruan/panggilan tuhan ini perlu dilakukan oleh Calvinisme, sebab pada waktu itu adalah masa dan situasi kapitalisme. Semangat yang berkembang di tengah masyarakat secara umum adalah semangat kapitalisme (spirit of capitalism). Masyarakat berusaha mencapai berbagai penghargaan, kehormatan, dan kemuliaan yang berwujud - status politik seperti peranan, kepemimpinan, dan kekuasaaan di tengah masyarakat, atau mencapai status ekonomi seperti kekayaan tanah dan pabrik, atau mencapai hubungan-hubungan sosial seperti gelar bangsawan.
Dalam perspektif seperti itu, Max Weber menyimpulkan bahwa etika protestan menjadi pendorong munculnya semangat kapitalisme. Dari simpulan Max Weber tersebut, para pengamat selanjutnya mengambil kesimpulan bahwa agama memiliki peran dalam kehidupan ekonomi. Sebagaimana pendapat Sobary, 1993, yang telah meneliti kelas bawah di Ciater dan berkesimpulan bahwa tidak hanya etika protestan yang berperan dalam kehidupan, namun dengan asumsi world view menyatu dalam tingkah laku, etika Islam juga berperan dalam kehidupan. Hal yang sama dikemukakan oleh Mu'tashim dan Munir Mulkhan, 1998, yang mengamati penganut Tarekat Sadzaliyah di Kudus, dan menyimpulkan bahwa pandangan umum yang menyatakan bahwa kaum sufi tidak memiliki etos kerja, tidak terjadi pada Tarekat Sadzaliyah. Pengikut Tarekat Sadzaliyah memiliki etos kerja tinggi dan jaringan bisnis. Satu-satunya perbedaan dengan kesimpulan penelitian sebelumnya, adalah bahwa kegiatan ekonomi produktif Tarekat Sadzaliyah ternyata tidak tumbuh besar.

\section{HIPOTESIS LAIN}

Namun demikian, dapat pula ditarik kesimpulan selain dari agama berperan dalam kehidupan. Misalnya saja pada penelitian Weber, yang mengemukakan ada dua gejala, pertama muncul gejala semangat kapitalisme di tengah masyarakat., kedua tranformasi makna Call pada penganut agama protestan, dapat pula ditarik kesimpulan paralelisasi, dan bukan pengaruh. Jadi ada paralelisasi antara etika protestan dengan kehidupan ekonomi, namun bukan berarti etika protestan mempengaruhi kehidupan ekonomi. Atau, dapat juga ditarik kesimpulan kehidupan ekonomi yang mempengaruhi transformasi makna Call dalam diri penganut Calvinisme.

Kesimpulan yang sama, juga dapat diambil dari hasil penelitian M. Sobary. Sebab Sobary, walaupun menggunakan metode grounded, namun mengasumsikan bahwa 
world view menyatu dalam tingkah laku. Dengan kata lain, Sobary mengasumsikan bahwa pada obyek yang diteliti, setiap tingkah laku 'alami' mencerminkan world view. Permasalahannya, world view adalah sesuatu yang abstrak, sementara tingkah laku adalah sesuatu yang terlihat dengan mudah, dan tingkah laku terbagi-bagi dalam - secara sederhana - tingkah laku ibadah dan tingkah laku hubungan sosial-ekonomi. Jika seseorang naik haji, atau hampir setiap hari tidur di mushola, atau melaksanakan shalat shubuh di mushola, hal itu menunjukkan bahwa dia telah melakukan tingkah laku ibadah, dimana tingkah laku tersebut mencerminkan world view ibadah. Namun demikian, dapatkah berdasarkan pola tingkah laku ibadah tersebut, ditarik kesimpulan bahwa tingkah laku sosialekonomi juga diwarnai oleh world view yang sama dengan world view ketika melakukan ibadah? Jawabnya belum tentu. Pada kenyataannya banyak orang yang tidak dan tidak taat beragama Islam mudah mengucapkan assalamu 'alaikum, insya Allah, atau alhamdulillah. Pada kenyataannya, banyak orang muslim yang tidak seperti seorang muslim. Menunjukkan bahwa dapat pula ditarik pula kesimpulan selain dari agania berpengaruh dalam kehidupan ekonomi. Boleh jadi kehidupan ekonomi mempengaruhi agama, boleh jadi kehidupan ekonomi dan agama paralel, atau bisa juga agama berperan dalam kehidupan ibadah namun tidak berperan dalam kehidupan sosial-ekonomi.

Demikian juga pada pendapat Radjasa Mu'tashim dan Abdul Munir Mulkan. Dimana mereka mengkonstruksikan kehidupan ekonomi dalam bentuk input-output perekonomian mikro. Masyarakat ekonomi memiliki input berupa, di antaranya etos kerja dan jaringan bisnis, yang dari keduanya akan menghasilkan kegiatan ekonomi produktif yang besar. Jika dilakukan 'treatment' Islam, sebagaimana pada tarekat Sadzaliyah, maka seharusnya terjadi peningkatan pada etos kerja dan keeratan jaringan bisnis yang berakibat pada peningkatan kegiatan ekonomi produktif. Namun dalam masyarakat tarekat Sadzaliyah, 'treatment' Islam meningkatkan input, namun tidak meningkatkan output. Dari hasil penelitian ini, dapatkah diambil kesimpulan bahwa agama berperan dalam kehidupan? Bukankah dari hasil penelitian ini dapat juga diambil suatu kesimpulan bahwa pelaku ekonomi bisnis dalam Tarekat Sadzaliyah tidak menikmati hasil kerja mereka? Bukankah hal ini juga dapat mengubah kesimpulan dari agama berperan dalam kehidupan menjadi agama sekadar al qodriyatu al ghoibiyah atau dalam bahasa Karl Marx, ilusi dan candu saja. Agama tidak berperan, namun agama dimanfaatkan pihak tertentu sehingga menyebabkan orang yang termanfaatkan dengan dalih agama tersebut berpikir dan berbuat sesuai dengan kehendak pihak tertentu tersebut, dan pihak tertentu itulah yang mendapatkan output, hasil, atau keuntungan.

Dengan demikian, terdapat berbagai kemungkinan hubungan agama dengan kehidupan ekonomi. Agama belum tentu menjadi variabel fungsional bagi kehidupan ekonomi. Manusia, dalam kehidupan ekonomi, mengambil apa saja, sedemikian rupa sehingga kehidupan ekonomi menjadi dinamik, maju, dan berkembang. Manusia menginginkan memiliki kondisi internal yang mendorong supaya dia mendapatkan kemajuan dan perkembangan, maka manusia mengambil halhal eksternal seperti agama, non agama, membenci agama, atau persaingan untuk mendorongnya mencapai kemajuan dan perkembangan. Berbagai kemungkinan tersebut, jika ditabulasikan sebagai berikut: 
Tabel 1. Kemungkinan Kesimpulan Selain Agama Mempengaruhi Kehidupan Ekonomi

\begin{tabular}{|c|c|c|c|c|}
\hline \multirow{2}{*}{$\begin{array}{l}\text { Peneliti dan } \\
\text { tema } \\
\text { penelitian }\end{array}$} & \multirow{2}{*}{ Asumsi } & \multirow{2}{*}{ Kesimpulan } & \multicolumn{2}{|c|}{ Kemungkinan Kesimpulan Lain, Jika Asumsi lain } \\
\hline & & & Kemungkinan Asumsi lain & Kemungkinan Kesimpulan Lain \\
\hline \multirow[t]{2}{*}{$\begin{array}{l}\text { Max Weber, } \\
\text { The Protestant } \\
\text { Ethic and The } \\
\text { Spirit of } \\
\text { Capitalism }\end{array}$} & \multirow[t]{2}{*}{$\begin{array}{l}\text { Dua gejala } \\
\text { menunjukkan } \\
\text { adanya } \\
\text { pengaruh }\end{array}$} & \multirow[t]{2}{*}{$\begin{array}{l}\text { Transformasi } \\
\text { Etika protestan } \\
\text { mempengaruhi } \\
\text { etos kerja }\end{array}$} & $\begin{array}{l}\text { Dua gejala berarti kejadian } \\
\text { paralel }\end{array}$ & $\begin{array}{l}\text { Terjadi transformasi etos protestan } \\
\text { dan terjadi semangat kapitalisme, } \\
\text { namun keduanya tidak saling } \\
\text { mempengaruhi }\end{array}$ \\
\hline & & & $\begin{array}{l}\text { Dua gejala berarti } \\
\text { berpengaruh sebaliknya }\end{array}$ & $\begin{array}{l}\text { Etos kerja di tengah Masyarakat } \\
\text { mempengaruhi terjadinya } \\
\text { transformasi etika protestant }\end{array}$ \\
\hline \multirow{2}{*}{$\begin{array}{l}\text { M. Sobary, } \\
\text { Kesalehan, } \\
\text { Etos Kerja, } \\
\text { dan Tingkah } \\
\text { Laku Ekonomi: } \\
\text { Studi Kasus } \\
\text { Sektor Informal } \\
\text { di Ciater }\end{array}$} & \multirow[t]{2}{*}{$\begin{array}{l}\text { Tingkah laku } \\
\text { menunjukkan } \\
\text { world view }\end{array}$} & \multirow{2}{*}{$\begin{array}{l}\text { Etika Islam } \\
\text { mempengaruhi } \\
\text { etos keja kelas } \\
\text { menengah dan } \\
\text { bawah }\end{array}$} & $\begin{array}{l}\text { Tingkah laku belum tentu } \\
\text { menunjukkan world view }\end{array}$ & \multirow{2}{*}{$\begin{array}{l}\text { Etika Islam tidak mempengaruhi } \\
\text { elos kerja }\end{array}$} \\
\hline & & & $\begin{array}{l}\text { Tingkah laku ibadah } \\
\text { menunjukkan world view } \\
\text { ibadah, namun belum tentu } \\
\text { menunjukkan world view sosial } \\
\text { ekonomi }\end{array}$ & \\
\hline $\begin{array}{l}\text { Radjasa } \\
\text { Mu'thasim dan } \\
\text { Abdul Munir } \\
\text { Mulkhan, } \\
\text { Bisnis Kaum } \\
\text { Sufi }\end{array}$ & $\begin{array}{l}\text { Separasi input } \\
\text { dan output } \\
\text { ekonomi. } \\
\text { 'treatment' } \\
\text { terhadap input } \\
\text { tidak } \\
\text { menyebabkan } \\
\text { perubahan } \\
\text { pada output }\end{array}$ & $\begin{array}{l}\text { Etika Islam } \\
\text { mempengaruhi } \\
\text { etos kerja dan } \\
\text { jaringan bisnis, } \\
\text { namun kedua- } \\
\text { nya tidak mem- } \\
\text { pengaruhi kegi- } \\
\text { atan ekonomi } \\
\text { produksi }\end{array}$ & $\begin{array}{l}\text { Separasi input dan output } \\
\text { ekonomi, 'treatment' tertadap } \\
\text { input menyebabkan perubahan } \\
\text { pada output }\end{array}$ & $\begin{array}{l}\text { 1. Ada 'variabel' lain yang lebih } \\
\text { dominan } \\
\text { 2. Ada 'kebocoran' }\end{array}$ \\
\hline
\end{tabular}

\section{LANDASAN TEORI}

\section{- Utilitarianisme}

Max Weber mengemukakan bahwa peradaban Eropa modern, yang dimulai sejak masa renaissance, yang kemudian dikenal sebagai peradaban Barat, memberikan perubahan signifikan terhadap seluruh aspek kehidupan. Dalam penilaiannya, konsep ilmu pengetahuan dan pengamatan empiris, kesenian, arsitektur, pejabat yang terpilih secara legal, dan terlatih secara teknik dan komersial, hingga pengorganisasian kelompok politik dan sosial dalam peradaban Eropa modern lebih mapan dari hal-hal yang sama pada peradaban yang lainnya.
Inner drive peradaban Barat adalah kedaulatan individu. Kemunculan kedaulatan individu terkait dengan melemahnya dominasi agama di Eropa. Pada waktu itu, kepercayaan publik terhadap agama sebagai pengatur kehidupan individu, masyarakat dan negara melemah. Selanjutnya dimunculkan kedaulatan individu sebagai pengganti dominasi agama. Kedaulatan individu, tanpa ada restriksi dan hambatan dari manapun akan menyebabkan keteraturan individu, masyarakat, dan negara lebih baik daripada ada pengaturan dari agama dan adanya restriksi dari negara.

Kedaulatan ekonomi individu dapat menyebabkan keteraturan perekonomian individu, masyarakat, dan negara, sebab 
kedaulatan ekonomi individu memunculkan mekanisme trial and error proccess. Bentuk riel dari trial and error proccess adalah memaksimalkan perbuatan hingga tercapai kedaulatan ekonomi individu tersebut. Seorang konsumen, misalnya, dia akan mengkonsumsi suatu produk hingga kedaulatan sebagai konsumen tercapai. Kemudian berhenti mengkonsumsi suatu produk, setelah kedaulatan konsumsi terpenuhi. Demikian pula seorang produsen, akan memproduksi untuk meraih kedaulatan sebagai seorang produsen dan tidak akan menambah produksi suatu produk jika kedaulatan produksi telah terpenuhi. Jadi perilaku setiap orang untuk memaksimalkan kedaulatan ekonomi individu memunculkan keteraturan individual. Semua individu melakukan trial and error process untuk memaksimalkan kedaulatan ekonomi individu dan berhenti melakukan trial and error process jika kedaulatan ekonomi individu telah tercapai.

Keteraturan trial and error process untuk mencapai kedaulatan ekonomi individu, selanjutnya akan menimbulkan equilibrium (keseimbangan) di tengah masyarakat. Sebab diasumsikan perbedaan tinggi rendahnya kedaulatan ekonomi di antara individu bersifat saling melengkapi satu dengan yang lain. Para ekonom biasa menggeneralisasi fenomena itu dalam the circular flow of economic activity. Walaupun untuk tujuan pembelajaran internal ilmu ekonomi, seringkali makna trial and error process, dan kedaulatan ekonomi individu yang saling melengkapi tidak dibahas.

Masyarakat dengan dua pelaku ekonomi utama, produsen dan konsumen, melakukan aktifitas trial and error process untuk mendapatkan kedaulatan individu. Produsen melakukan aktifitas produksi-distribusi dan konsumen melakukan aktifitas konsumsi dan aktifitas terlibat dalam proses produksi. Equilibrium tercapai sebab terjadinya economic activity terkait dari pelaku yang lain. Seandainya dimulai dari perilaku produksi, produsen melakukan aktifitas produksi dan distribusi untuk meraih kedaulatan produksi dengan menggunakan faktor produksi dari konsumen. Ketika produsen membutuhkan faktor produksi tenaga kerja, misalnya, produsen mendapatkannya dari para konsumen. Para konsumen bersedia menjadi faktor produksi karena untuk meraih kedaulatan berupa mendapatkan balas jasa faktor produksi, yaitu dalam hal ini upah. Selanjutnya, balas jasa yang diperoleh digunakan para konsumen untuk membeli produk meraih kedaulatan konsumsi. Perlu diingat, konsumen dapat membeli produk, karena produsen telah mendistribusikan produknya kepada konsumen, untuk mendapatkan kepuasan produksi. Jadi, terjadi saling keterkaitan satu dengan yang lain.

Trial and error process, saling keterkaitan antarpelaku ekonomi, dan ekuilibrium terjadi karena individu utilizing - dan oleh karena itulah masyarakatnya disebut 'berideologi' utilitarianisme - kedaulatan ekonomi individu. Diasumsikan dalam diri setiap individu terdapat dua karakter yang menyertai kedaulatan individu. Pertama adalah karakteristik yang disebut sebagai logical extreme, yaitu seperti yang digambarkan oleh Jeremy Bentham: "Hal yang mendasari seseorang untuk melakukan aktifitas adalah untuk mendapatkan kesenangan dan menghindari kesusahan" (Ekelund dan Hebert, 1997). Adapun karakteristik kedua adalah spirit of capitalism, seperti yang digambarkan oleh Max Weber: "Kejujuran sangatlah berguna, sebab kejujuran menjamin kredit; dan juga ketepatan waktu, sikap rajin dan hemat dan itulah alasan mengapa itu semua merupakan kebajikan". Kedua hal inilah, logical extreme dan spirit of capitalisme, menjadi pendorong bagi trial and error proccess dan kedaulatan ekonomi individu menuju pada ekuilibrium, yaitu menyebabkan keteraturan alamiyah individu, masyarakat, dan negara, tanpa perlu adanya pembatasan dan restriksi.

Walaupun diharapkan keduanya mendorong kedaulatan ekonomi individu untuk 
mencapai keteraturan yang alami pada individu, masyarakat, dan negara, pada kenyataannya keduanya justru saling bertentangan. Logical extreme dan spirit of capitalism terbukti menjadi faktor negatif. Banyak pengkritik mengkaitkan keduanya dengan hedonism.

\section{- Agama Sebagai Self Monitoring}

Adam Smith, dalam buku karyanya The Theory of Moral Sentiment menggambarkan bentuk, posisi, dan peran agama dalam ruang dan waktu masyarakat dimana dominasi kedaulatan individu besar. Sebagaimana pandangan para teolog pada waktu itu - yang baru saja dan sedang 'terguncang' dengan rennaisance, Adam Smith menganggap semua agama sama baiknya selama berada dalam domain ritual dan tidak masuk dalam domain preferensi individual, masyarakat, dan negara. Kebalikannya, semua agama sama jeleknya, jika mempengaruhi preferensi individual, masyarakat, dan negara.

Posisi dan peran agama, menurut Adam Smith, sebagaimana dikemukakan oleh West (1992), adalah sebagai self monitoring. Edwin G. West menyimpulkan hal itu setelah mempelajari pemikiran Adam Smith mengenai perlunya 'exogenous' punishment or threat of punishment. Masyarakat yang diibaratkan sebagai suatu supergames, mencapai ekuilbrium jika di antara pelaku supergames, memilih strategi cooperative. Hal itu dapat terjadi jika pelaku supergames sedikit dan tindakan noncooperative akan menghasilkan punishment bagi pelaku noncooperative. Namun, jika pelaku supergames relatif banyak, tindakan noncooperative di antara pelaku supergames tidak dapat menghasilkan sesuatu yang dirasakan sebagai punishment. Maka, harus ada suatu hal di luar supergames yang mampu menggambarkan bahwa tindakan noncooperative mendatangkan punishment. Jadi, supaya terjadi ekuilbrium dalam supergames, harus ada 'exogenous' punishment or threat of punishment yang menghalangi pelaku supergames dari tindakan noncooperative.

Agama, menurut Adam Smith, dapat berperan dengan baik sebagai 'exogenous' punishment or threat of punishment. Hal itu karena Adam Smith meyakini bahwa tuhan telah menanamkan moral keadilan dalam diri setiap manusia. Jika menggunakan kalimat Levy: "Kebencian kita atas ketidakadilan adalah sesuatu yang memang sudah tertanam dalam diri kita ...". Dorongan agama, yang menanamkan keadilan dan membenci ketidakadilan, diharapkan akan menjadi faktor yang menentukan manusia supaya menghormati hukum yang berlaku. Karena hukum yang berlaku dalam supergames adalah cooperative, maka strategi yang dipilihpun adalah cooperative sehingga supergames mencapai ekuilibrium. Jadi agama memonitor diri manusia itu sendiri untuk melakukan tindakan terbaik.

Hanya saja, Adam Smith khawatir kejadian masa lalu akan terulang, dimana dominasi agama mengalahkan kedaulatan individu. Oleh karena itu, Adam Smith berpendapat lebih baik terdapat banyak agama atau sekte daripada terdapat satu agama di tengah masyarakat. Adanya satu agama mayoritas di tengah masyarakat menyebabkan kedaulatan individu hilang. Sedangkan adanya penampakan banyak agama atau sekte di tengah masyarakat akan menyebabkan agama dirasakan sebagai terror of religion terhadap tindakan tidak menghormati hukum yang berlaku. Kedaulatan individu terjaga, dan di sisi lain moralitas cooperative dalam supergames muncul karena dorongan agama, maka terjadilah ekuilibrium.

\section{ANALISIS}

Salopek, 2000, mengemukakan hasil survey terhadap lebih dari 90 manajer level atas dan para eksekutif yang dilakukan oleh Ian Mitroff dan Elizabeth Denton. sebagai berikut: 
1. Respondents agreed nearly unanimously on the definition of spirituality: "The basic desire to find ultimate meaning and purpose in one's life and to live an integrated life".

2. People don't want to compartmentalize or fragment their lives: they especially want to be acknowledged as whole persons in the workplace.

3. People differentiate strongly between religion and spirituality. Religion is viewed as intolerant and divisive. Spirituality is seen as universal and broadly inclusive.

4. Workers at organizaitions, they perceive as more spiritual also consider their companies more profitable, and report that they are able to deploy more of their fill creativity, emotions, and intelligence.

Walaupun dengan responden eksekutif dan manajer level atas, dan secara umum menggambarkan workplace dan workers, ternyata kesimpulan yang diperoleh dalam survei tersebut bersifat umum. Sebagai contoh, kesimpulan nomor 3, People differenciate strongly between religion and spirituality, menggambarkan situasi umuin masyarakat Amerika Serikat. Donna R. Runnals, 2001, mengemukakan bahwa salah satu kata yang populer di Amerika Serikat adalah spirituality. Bahkan menurutnya, kata spirituality digunakan oleh anggota kelompok keagamaan maupun yang menolak adanya kelompok keagamaan.

Kenyataan ini menggambarkan bahwa manusia membutuhkan inner drive. Sebagaimana pendapat Adam Smith di atas bahwa manusia perlu self monitoring. Adapun agama (religion, spiritualism) bukan merupakan satusatunya inner drive, dan ada kecenderungan pada saat ini agama tidak signifikan dalam kehidupan ekonomi masyarakat.

Adapun kecenderungan inner drive di tengah masyarakat adalah spirit of capitalism-kedaulatan dan kepuasan individu. Hal itu dapat dibuktikan melalui simbol-simbol keagamaan dalam kehidupan moneter umat
Islam. Sebagai contoh, perbankan syariah sebagai simbol moneter umat Islam ternyata lebih kental simbol spirit of capitalism daripada simbol agama. Para pemilik bank syariah lebih suka menggunakan istilah bank syariah daripada bank tanpa bunga atau bebas bunga. Padahal diferensiasi normatif bank syariah dengan bank konvensional adalah larangan bunga (riba). Jadi, seharusnya pemilik perbankan syariah lebih menyukai istilah bank tanpa bunga atau bank bebas bunga. Namun, pada kenyataannya, pemilik perbankan syariah tidak menyukai istilah bank tanpa bunga atau bank bebas bunga, karena bunga dalam pengertian ekonomi moneter adalah biaya. Jadi jika disebut bank tanpa bunga atau bank bebas bunga, para pemilik perbankan syariah khawatir jika bank syariah diberi makna oleh nasabah sebagai bank tanpa atau bebas biaya, atau semua serba gratis. Jika demikian adanya, ada kekhawatiran bahwa kedaulatan produsen pada pemilik perbankan syariah akan hilang, sebab atas jasa yang diberikan, tidak dapat memungut biaya. Oleh karena itu, pemilik perbankan syariah lebih menyukai istilah syariah.

Di sisi lain, pemilihan istilah syariah atau muamalah, dan yang sejenis dengan hal itu sesungguhnya lebih mencerminkan bagian dari strategi pemasaran daripada spirit keagamaan. Sebab jasa keuangan yang ditawarkan pemilik perbankan syariah kepada nasabah sebenarnya adalah konsep bagi hasil atau dalam bentuk luas adalah profit-lost sharing. Sehingga istilah standar bagi bank syariah adalah bank bagi hasil. Namun, perbankan syariah lebih menyukai istilah bank syariah daripada istilah standar, bank bagi hasil, dengan pertimbangan mendekatkan pada pasar yang dibidik. Perbankan syariah melayani para nasabah muslim, dimana diasumsikan para nasabah muslim familiar dengan istilah-istilah arab dan keagamaan, maka untuk mendekatkan perbankan dengan para nasabahnya digunakan istilah syariah, muamalat daripada istilah bagi hasil. 
Dalam praktek pembiayaan, juga ditemukan berbagai kecenderungan spirit of capitalism mengalahkan spirit keagamaan. Beberapa waktu yang lampau, sebuah bank syariah kecil didatangi oleh seorang pengrajin patung. Pengrajin patung yang mendapatkan order dari luar negeri menemui pimpinan bank syariah tersebut dan meminta supaya kegiatannya dibiayai. Pimpinan bank, setelah mempertimbangkan aspek produk, yaitu pembuatan patung, menolak untuk membiayai dengan alasan tidak sesuai dengan agama.

Pengrajin patung tidak bisa menerima alasan tersebut, dan melaporkan hal tersebut kepada dewan pengawas syariah pada bank syariah tersebut, yang terdiri para 'ahli' agama dan bertugas untuk 'mendudukkan' segala hal dalam bank syariah tersebut sesuai dengan ajaran Islam. Dewan pengawas syariah, berdasarkan pertimbangan ekspor dan membuat patung dan gambar dalam hukum islam masih belum jelas dan banyak ikhtilaf, kemudian menganulir keputusan pimpinan bank syariah dan 'memaksa' pimpinan bank syariah untuk mengucurkan dana bagi si pengrajin patung.

Kesimpulan yang dapat ditarik dari kejadian tersebut, ternyata dewan pengawas syariah yang merupakan simbol keagamaan dalam aktifitas perbankan syariah justru mengedepankan spirit of capitalism. Sebuah bank syariah, yang kecil, mendapatkan kehormatan membiayai ckspor, sangat langka. Seorang pengrajin patung mendatangi bank syariah, sangat langka pada waktu itu. $\mathrm{Hal}$ ini merupakan peluang berharga yang bermanfaat untuk mendapatkan keuntungan. Tentu saja sangat disayangkan jika hal itu harus hilang hanya karena pernyataan dilarang dalam ajaran Islam. Terlepas dari masalah benar atau salah, hal ini menunjukkan bahwa pada simbol keagamaan dalam aktifitas perbankan syariah yaitu dewan pengawas syariah, inner drive keagamaan menjadi sub dari spirit of capitalism.

Adapun para nasabah yang menabung di bank syariah, lebih disemangati oleh semangat keagamaan daripada semangat spirit of capitalism. Mereka menabung di bank syariah bukan dilandasi oleh maksimalisasi return, namun disemangati oleh semangat keagamaan, misalnya semangat dimurkai Allah SWT jika melakukan riba. Namun demikian, perilaku ini masih perlu dicermati secara mendalam. Sebab sejak dahulu, di perbankan konvensional, telah ditengarai bahwa perilaku menabung untuk mendapatkan return tidak terlalu signifikan. Para penabung di bank konvensional tidak terlalu tertarik pada perubahan tingkat suku bunga tabungan. Seorang penabung di bank $\mathrm{A}$ tidak terlalu tertarik untuk memindahkan tabungannya ke bank B, jika bank B menaikkan tingkat suku bunga tabungan. Jika hal itu terjadi secara umum, baik pada nasabah bank konvensional dan bank syariah, maka kesimpulan awal bahwa perilaku nasabah bank Syariah yang lebih didominasi semangat keagamaan menjadi kurang kuat. Boleh jadi, lebih semangat keagamaan lebih dominan daripada spirit of capitalism adalah cara nasabah bank syariah membahasakan dengan bahasa agama - ketidaktertarikan mereka dengan suku bunga tabungan, bukan murni semangat keagamaan.

\section{KESIMPULAN}

Kemungkinan hubungan antara agama dengan kehidupan pada masyarakat utilitarianisme tetap ada. Jika dorongan logical extreme lebih besar daripada spirit of capitalism, maka agama sebagai faktor eksternal dapat digunakan sebagai self monitoring, baik untuk mengurangi bahaya logical extreme atau memperbesar spirit of capitalism. Namun, dalam keadaan umum, dimana spirit of capitalism eksis, maka faktor luar seperti agama tidak diperlukan. Bahkan eksistensi agama dapat mengganggu atau menyebabkan kemunduran spirit of capitalism.

Pada kenyataannya, manusia memerlukan suatu inner drive. Inner drive inilah yang mempengaruhi perbuatan manusia. Permasalahannya, inner drive, atau world view berbentuk 
abstrak. Untuk mengkongkritkan suatu yang abstrak tidaklah mudah. Dengan kata lain pertanyaan yang harus dijawab adalah: "Simbolisasi apa yang tepat untuk menunjukkan inner drive apa?" "Apakah sholat, puasa, atau haji dalam agama Islam adalah simbolisasi inner drive penganut agama Islam? Sebagaimana attendance (kedatangan ke gereja) adalah simbolisasi dari inner drive agama Kristen?" Pertanyaan yang sama juga harus diajukan untuk simbolisasi kehidupan. Apakah seseorang yang bekerja keras mencari uang, dan meraih berbagai kedaulatan dan kepuasan individual berarti menunjukkan spirit of capitalism? Bisakah pengamatan berulangulang atau pengamatan mendalam menjadi alasan bahwa inner drive yang abstrak dapat didekati oleh simbol-simbol keagamaan?

Meletakkan asumsi dasar berupa suatu struktur masyarakat tertentu, dapat membantu untuk menentukan jenis hubungan dan ketidakhubungan antara agama dengan kehidupan ekonomi. Sebab suatu struktur masyarakat pasti memiliki berbagai simbol masyarakat tersebut. Misalnya, masyarakat kapitalistik memiliki simbol kapitalistik di bidang moneter berupa lembaga investasi dan lembaga keuangan. Atau di bidang politik ada lembaga presiden, perdana menteri, partai, atau legislatif. Simbol dan struktur inilah yang ingin diraih oleh anggota masyarakat.

Jika berbagai simbol tersebut sudah mencapai ekuilibrium, maka tidak diperlukan dorongan dari simbol-simbol lain yang merupakan substruktur dari struktur utama masyarakat. Nasionalisme, misalnya, digunakan oleh Werner Sombart dan para pengikut Germany Historical School, untuk memperkuat kapitalisme Jerman pada era Nazi (Brue, 2001), karena ada kekhawatiran bahwa kapitalisme Jerman tidak mencapai suatu ekuilibrium. Demikian juga substruktur agama dan keyakinan dalam struktur masyarakat kapitalistik bersama-sama simbolnya dapat dimanfaatkan untuk memperkuat simbol- simbol masyarakat kapitalistik supaya lebih cepat mencapai ekuilibrium.

Namun bagaimanakah bila yang disebut sebagai ekuilibrium adalah suatu hal yang relatif nisbi, demikian juga kedaulatan dan kepuasan individu? Atau dalam bahasa lain, terjadi logical extreme? Sementara dalam sejarah utilitarianisme justru hal inilah yang terjadi, seperti eksploitasi kelompok kaya dan penguasa, atau peredaran uang dan berbagai fasilitas penting hanya di kalangan elite. Apakah agama hanya menjadi salah satu simbol perlawanan ataukah agama hanya menjadi salah satu simbol untuk meredam keresahan di tengah masyarakat? Apapun pilihannya, semua bisa mencapai ekuilibrium, kecuali agama itu sendiri.

\section{DAFTAR PUSTAKA}

Brue, Stanley L. 2000. The Evolution of Economic Thought. Fort Worth: The Dryden Press.

Ekelund Jr., Robert B dan Hebert, Robert F. 1997. A History of Economic Theory and Method. New York: McGraw-Hill Companies Inc.

Mu'tashim, Radjasa dan Munir Mulkhan, Abdul. 1998. Bisnis Kaum Sufi. Jogyakarta: Pustaka Pelajar.

Runnals, Donna R.. 2001. Spiritualism, and Civil Religion: A Threat for Religion? (Dalam buku Agama Spiritualisme dalam Dinamika Ekonomi Politik dengan editor Maryadi dan Syamsuddin). Surakarta: Muhammadiyah University Press.

Salopek, Jenifer J. 2000. "For God and Company". Training and Development, March 2000.

Sobary, Mohammad. 1993. Kesalehan Etos kerja, dan Tingkah Laku Ekonomi: Studi Kasus Sektor Informal di Ciater. (Dalam buku Membangun Martabat Manusia dengan editor Sofian Effendi, dkk). Jogyakarta: Gadjah Mada University Press 
Weber, Max. 2000. Etika Protestan dan Semangat Kapitalisme (diterjemahkan dari The Protestant Ethics and the Spirit of Capitalism). Surabaya: Pustaka Promethea.
West, Edwin G. 1992. Adam Smith and Modern Economics. Vermont: Edward Elgar Publishing Company 